\title{
Notices of Archaeological Publications
}

\section{F. W. R.}

To cite this article: F. W. R. (1915) Notices of Archaeological Publications, Archaeological Journal, 72:1, 87-88, DOI: 10.1080/00665983.1915.10853290

To link to this article: http://dx.doi.org/10.1080/00665983.1915.10853290

$$
\text { 曲 Published online: } 17 \text { Jul } 2014 .
$$

Submit your article to this journal $\widetilde{3}$

III Article views: 2

Q View related articles $\asymp$ 


\section{NOTICES OF ARCHAEOLOGICAL PUBLICATIONS.}

PREHISTORIC LONDON : ITS MOUNDS AND CIRCLES. By E. O. GoRdON. $9 \times 6$, xii +212 pp. 22 plates. London : Elliot Stock. I9I4. Ios. $6 \mathrm{~d} . \mathrm{n}$.

In case it might be supposed from the title that this book endeavoured to deal with the question of prehistoric London, it may be well to say at once that it is merely a farrago of fancy built on the fables of the Romanticists and the quaint notions of Stukeley, interwoven with the inventions of modern Welsh national revivalists.

We are told a great deal about druids, Stonehenge, Glastonbury, Troy, Babylon, etc. but little reference is made to London, and for the most part any such allusions are inaccurate.

Certain hills and mounds in the neighbourhood of London are assumed, quite arbitrarily, to have formed a system of druidic places of worship. Keltic names are boldly invented for them, or if the existing name lends itself to a Keltic derivation it is promptly pressed into service regardless of how modern may be its origin. As an example Pentonville is glorified as the 'Pen-ton (Pen signifying in Keltic a hill rounded like a head).' Perhaps it may be consoling to Henry Penton, esquire, who died just over a century ago, that at this time he at least is not considered to have been a ' tete carree.' Connected with this district an opportunity has been missed in failing to mention the celebrated mounds near Battle Bridge. There is no question as to these having been artificial, while their antiquity is as great or perhaps greater than that of the name of 'Penton.' They never seem to have been known by any other name than the ash or rubbish heaps, but as Parliament hill is renamed 'Llan-din' these mounds might have been similarly dignified.

Of course Gospel Oak is associated with the druids, as is also Maiden lane. There have been people irreverent enough to suggest that this is only a corruption of Midden lane from the aforesaid rubbish heaps.

Having settled the sacred antiquity of Pentonville hill the author claims the inherent probability of king Arthur's astronomer having established his observatory in the neighbourhood, evidence of which is provided by the public house known as 'Merlin's Cave.'

'An underground passage at the bottom of the hill led to the cave; the entrance to which, in the cellars of Merlin's Cave Tavern, has only recently been bricked up, the passage being considered no longer safe.' Whatever truth there may be as to a subterranean passage, there is no doubt that the present squalid public house derives its name from an attraction added in $174^{\circ}$ to the gardens of the 'New Wells,' which was an imitation of the grotto constructed in the royal gardens at Richmond by the order of the consort of George II in $\mathbf{1 7 3 5}$. 
London Stone, we are told, is the 'index-stone' connected with an imaginary druidic circle supposed to have occupied the site of St. Paul's. In the first case it is admitted that no actual evidence of such a circle has been found, but the name College street is presumed to be the survival of this druidic seat of learning, from which we may suppose that 'Dick Whittington,' in founding a college here early in the fifteenth century, was led to do so because the street was already so named.

The number of assumed sacred mounts in the neighbourhood of London, we are told, forms unmistakable evidence of the large population and great importance of the capital in remote antiquity.

It is also claimed that the objects in our museums give support to this view. A great deal is made out of the marshes which are said originally to have surrounded the elevated ground on which the city stands, and from the marshes on the north the stream of the Walbrook is said to have had its source. ' The City Mile,' we are told, probably covers more buried history than any other mile in the world. Be this as it may, the evidence yielded by the soil of London has, in this book, been totally ignored or grossly distorted.

That any considerable settlement existed on the site, before Londinium was founded by the Romans, has been abundantly disproved by the great paucity of relics of earlier periods. Such objects as are shown in our museums come mostly from the outlying districts or from the bed of the Thames, remains of settlements of the bronze and early iron ages have been found higher up the river, but in London itself no evidence of any settlement earlier than the Roman period has yet come to light.

Sir Laurence Gomme's oft-repeated error as to Keltic pile-dwellings in the Fleet is naturally seized on to support the argument, while all the relics of the early and late stone, the bronze and early iron ages are subtly confused together as if they represented the traces of one race of people, the Kymry, whose principal business was druidism.

The examination of the soil of London has proved clearly that the marshes north of the city did not come into existence until long after Londinium had been founded. When the Romans enclosed their city, the Walbrook was flowing freely over a clean, gravelly surface. Culverts were constructed for carrying the stream through the wall, and it was not until later times that neglect of these passages caused the waters to accumulate on the north of the city wall. Had the elementary facts of the earlier history of London been known to the author, this book would never have appeared under its present title, and much that it contains would never have been written except, perhaps, as a romance. Stukeley, whose name is synonymous with all that is extravagant and fantastic in archaeology, was sufficiently candid to warn his readers that his writings were not a mere relation of history, but a means for the improvement of the morals of mankind. The writer of Prebistoric London gives no such warning, but may have been animated with a similar idea.

The book in fact may be excellent morality, but with this we are not concerned; to look to it for reliable information on the prehistory of London will be labour in vain.

F. W. R. 